\title{
Perbedaan Praktik Pemberian Makan dan Status Ketahanan Pangan Rumah Tangga pada Balita Status Gizi Kurang dan Normal
}

\section{The Differences of Feeding Practice and Household Food Security between Toddler with Underweight and Normal Nutritional Status}

\author{
Rizqiyah Fitri Nafadza*, Annas Buanasita ${ }^{1}$, Triska Susila Nindya ${ }^{2}$
}

\begin{abstract}
ABSTRAK
Latar Belakang: Gizi kurang adalah masalah gizi pada balita yang disebabkan oleh beberapa faktor. Faktor yang secara langsung berhubungan dengan status gizi adalah asupan zat gizi dan riwayat penyakit infeksi. Sementara itu, faktor tidak langsung yang mempengaruhi diantaranya praktik pemberian makan, status ketahanan pangan rumah tangga dan kesehatan lingkungan.

Tujuan: Tujuan dari penelitian ini adalah untuk menganalisis perbedaan praktik pemberian makan dan status ketahanan pangan rumah tangga pada balita status gizi kurang dan normal.

Metode: Penelitian ini merupakan penelitian observasional analitik dengan desain cross sectional. Sampel penelitian terdiri dari 80 balita usia 6-24 bulan di Kelurahan Tanah Kali Kedinding Kota Surabaya dengan masing-masing balita gizi kurang dan normal berjumlah 40 balita. Pengumpulan data dilakukan menggunakan metode wawancara dengan kuesioner, FFQ dan recall 24 jam untuk praktik pemberian makan serta US-HSFFM (United State of Household Food Security Survey Module) untuk ketahanan pangan rumah tangga. Data dianalisis menggunakan uji Mann-Whitney.

Hasil: Praktik pemberian makan yang baik pada balita gizi normal sebesar $15 \%$ sedangkan pada balita gizi kurang sebesar $7,5 \%$. Balita gizi normal yang berasal dari keluarga tahan pangan yaitu $62,5 \%$ sedangkan gizi kurang yaitu $32,5 \%$. Hasil penelitian menunjukkan adanya perbedaan praktik pemberian makan $(p=0,032)$ dan status ketahanan pangan rumah tangga $(p=0,012)$ pada balita status gizi kurang dan normal.

Kesimpulan: Terdapat perbedaan praktik pemberian makan dimana balita dengan status gizi normal mendapatkan pemberian makan yang lebih baik apabila dibandingkan dengan balita gizi kurang. Terdapat perbedaan status ketahanan pangan rumah tangga, balita dengan status gizi normal lebih banyak berasal dari rumah tangga tahan pangan.
\end{abstract}

Kata Kunci: gizi kurang, praktik pemberian makan, status ketahanan pangan rumah tangga

\section{ABSTRACT}

Background: Underweight is a problem caused by many factors, factors that directly affect nutritional status are nutritional intake and infectious disease. Meanwhile, indirect factors that affecting nutritional status is feeding practices, household food security and environmental health.

Objectives: The objective of this study was to analyze the differences of feeding practice and household food security between toddlers with underweigt and normal nutritional status.

Methods: The research was an observational analytic with cross sectional design. The sample was 80 toddlers from 6-24 months in Tanah Kali Kedinding Sub-District, Surabaya. They are consist of 40 normal and 40 underweight toddlers. Data was collected by interview using questionnaire, FFQ, recall 24 hours and US-HSFFM for household food security. Data were analyzed by using Mann-Whitney Test.

Results: Good feeding practice for normal toddlers was $15 \%$ while for underweight toddlers was $7.5 \%$. Toddlers with normal nutritional status come from secure household was $65.5 \%$ while underweight toddlers was $32.5 \%$. The result found there was a difference of feeding practice $(p=0.032)$ and household food security $(p=0.012)$ between toddlers with underweight and normal nutritional status.

Conclusion: There was difference in feeding practices, toddlers with normal nutritional status get better feeding practice than toddlers with underweight. There was difference in the household food security, toddlers with normal nutritional status mostly come from secure households.

Keywords: underweight, feeding practice, household food security. 


\author{
*Koresponden: \\ fitrinafadza11@gmail.com \\ ${ }^{1}$ Akademi Gizi Surabaya, Jl. Bendul Merisi No.126, Wonocolo, 60239, Surabaya, Jawa Timur, Indonesia \\ ${ }^{2}$ Departemen Gizi Kesehatan, Fakultas Kesehatan Masyarakat, Universitas Airlangga \\ Kampus C Mulyorejo, 60115 Surabaya, Jawa Timur, Indonesia
}

\section{PENDAHULUAN}

Gizi memegang peranan penting dalam siklus hidup manusia, pada dasarnya masalah gizi masih menjadi masalah kesehatan masyarakat utama di Indonesia. Salah satu kelompok masyarakat yang rentan terhadap masalah gizi adalah kelompok balita, gangguan pertumbuhan dan perkembangan dapat terjadi pada masa balita akibat kekurangan gizi yang apabila tidak diatasi secara dini dapat berlanjut hingga dewasa ${ }^{1}$. Masalah gizi yang sering terjadi pada masa balita antara lain gizi kurang, stunting, obesitas dan kurang vitamin $\mathrm{A}^{2}$.

Prevalensi masalah gizi kurang pada balita usia 0 - 23 bulan di Indonesia menurut indeks BB/U pada tahun 2016 sebesar 11,8\%, angka tersebut mengalami penurunan 0,1\% jika dibandingkan dengan tahun 2015 dengan prevalensi sebesar $11,9 \%$ persen $^{3}$. Di Provinsi Jawa Timur, prevalensi balita usia $0-23$ bulan yang mengalami gizi kurang sebesar $12,9 \%$, angka tersebut berada di atas rata-rata nasional pada tahun 2015 yaitu sebesar 11,9\%. Pada tahun 2016 terjadi penurunan prevalensi gizi kurang di Jawa Timur menjadi $11,0 \%$ dan angka tersebut berada di bawah rata-rata nasional pada tahun 2016 sebesar $11,8 \%{ }^{3}$.

Persentase balita yang BGM (Bawah Garis Merah) di Kota Surabaya pada tahun 2014 sebesar 0,88\%, pada tahun 2015 terjadi penurunan menjadi 0,7\% kemudian pada tahun 2016 mengalami kenaikan sebesar 0,6\% menjadi 0,76\% $\%^{4,5,6}$. Puskesmas Tanah Kali Kedinding merupakan salah satu puskesmas dengan prevalensi balita gizi kurang yang cukup tinggi di Kota Surabaya pada tahun 2015 yaitu sebesar 14,13\% yang terdiri dari balita gizi kurang $12,5 \%$ dan gizi buruk $1,63 \%$.

Status gizi balita dapat dipengaruhi oleh berbagai faktor, penyebab langsung yang berhubungan dengan status gizi adalah riwayat penyakit infeksi dan pemenuhan asupan zat gizi, kedua faktor yang saling mempengaruhi tersebut terkait dengan berbagai penyebab tidak langsung antara lain praktik pemberian makan dan status ketahanan pangan rumah tangga. Salah satu aspek penting dalam praktik pemberian makan adalah praktik pemberian ASI serta penyusunan dan pemberian MP-ASI. ASI merupakan makanan terbaik saat masa bayi, namun dengan bertambahnya usia dan kebutuhan semakin meningkat, perlu diberi makanan pendamping ASI (MP-ASI) karena ASI saja tidak dapat memenuhi kebutuhan gizi balita ${ }^{7}$. Masalah praktik pemberian MP-ASI pada balita masih sering terjadi di kalangan masyarakat seperti pemberian MP-ASI dini, jumlahnya terlalu sedikit, jenis MP-ASI tidak sesuai dengan usia balita dan frekuensi pemberian MP-ASI masih kurang ${ }^{8}$. Penelitian yang pernah di Kelurahan Tanah Kali Kedinding mendapatkan hasil bahwa masih banyak balita yang tidak mendapat ASI eksklusif sampai usia 6 bulan dan mulai memberikan makanan selain ASI diusia 3 bulan berupa pisang lumat yang dicampur nasi ${ }^{9}$.
Penyebab tidak langsung lain yang mempengaruhi status gizi adalah status ketahanan pangan rumah tangga. Balita dengan status gizi pendek dan berat badan kurang memiliki hubungan yang signifikan dengan status kerawanan pangan rumah tangga ${ }^{10}$. Pada rumah tangga yang rawan pangan, kemampuan untuk membeli makanan akan menurun sehingga tidak dapat memenuhi kebutuhan makan, hal tersebut apabila terjadi dalam waktu lama akan berpengaruh terhadap status gizi balita ${ }^{10}$. Menurut Global Food Security Index (GFSI) tahun 2017 tingkat ketahanan pangan Indonesia berada pada peringkat 69 diantara 113 negara dan berada di bawah 4 negara ASEAN yakni Singapura (4), Malaysia (41), Thailand (55), dan Vietnam $(64)^{11}$. Pada tingkat nasional, Badan Ketahanan Pangan (BKP) Kementerian Pertanian menyatakan terdapat $12,6 \%$ penduduk yang sangat rawan pangan, $27,16 \%$ penduduk tergolong rawan pangan dan $60,15 \%$ penduduk Indonesia yang tergolong tahan pangan. Secara umum, jumlah penduduk yang rawan pangan mengalami penurunan dari tahun 2012 2014 sementara jumlah penduduk yang tahan pangan mengalami kenaikan ${ }^{12}$.

Ketahanan pangan di Jawa Timur telah meningkat dari tahun 2010 hingga 2015, adanya peningkatan status ketahanan pangan merupakan dampak dari perbaikan pada indikator ketahanan pangan dan gizi ${ }^{13}$. Kota Surabaya termasuk wilayah dengan risiko kerawanan pangan yang rendah. Namun demikian, ketahanan pangan di tingkat individu dan rumah tangga belum bisa terjamin meskipun pada tingkat nasional dan regional dikategorikan tahan pangan ${ }^{14}$. Demikian pula di Surabaya, masih ada beberapa wilayah yang berisiko mengalami kerawanan pangan akibat kemampuan rumah tangga dalam mengakses dan menyediakan pangan rumah tangga belum merata.

Tujuan penelitian ini adalah menganalisis perbedaan praktik pemberian makan dan status ketahanan pangan rumah tangga pada balita dengan status gizi kurang dan normal di Kelurahan Tanah Kali Kedinding Kecamatan Kenjeran Kota Surabaya. Penelitian ini penting untuk dilakukan sebagai bahan tambahan kajian tentang masalah gizi kurang pada balita dimana masalah gizi kurang dapat dipengaruhi berbagai aspek baik aspek spesifik maupun aspek sensitif, sehingga hasil penelitian ini dapat dijadikan bahan pertimbangan dalam menyusun program atau kebijakan untuk mengatasi masalah gizi kurang.

\section{METODE}

Penelitian ini merupakan penelitian observasional analitik dengan desain cross sectional. Sampel penelitian adalah balita usia 6-24 bulan di Kelurahan Tanah Kali Kedinding, Kecamatan Kenjeran, 
Kota Surabaya dan responden penelitian merupakan ibu balita. Jumlah sampel yang didapatkan sebanyak 80 responden dengan masing-masing kelompok berjumlah 40 responden. Pemilihan sampel dilakukan melalui metode simple random sampling dengan kriteria inklusi balita berusia 6-24 bulan saat wawancara, balita tidak dalam kondisi sakit, tidak mengalami cacat bawaan dan ibu balita bersedia untuk diwawancarai.

Data dikumpulkan melalui wawancara menggunakan kuesioner terstruktur yang meliputi karakteristik keluarga (pendidikan, pendapatan, pengeluaran untuk makan, dan jumlah anggota dalam keluarga) dan balita (usia dan jenis kelamin), praktik pemberian makan dan status ketahanan pangan rumah tangga. Kuesioner praktik pemberian makan merupakan kuesioner yang berisi praktik pemberian ASI dan MP-ASI yang meliputi 8 indikator antara lain inisiasi menyusu dini, ASI eksklusif, keberlanjutan ASI, tekstur MP-ASI, frekuensi MP-ASI, Food Frequency, keberagaman jenis MP-ASI dan konsumsi makanan mengandung zat besi $(\mathrm{Fe})^{15}$. Pada kuesioner pemberian makan digunakan pula instrumen berupa recall 24 jam dan Food Frequency Questionnaire (FFQ) pada 7 kelompok makanan yaitu serealia dan umbi-umbian, kacang-kacangan, produk olahan susu, daging dan ikan, telur, buah dan sayur mengandung vitamin A dan serta buah dan sayur lainnya. Penghitungan skor variabel praktik pemberian ASI dan MP-ASI didapatkan dari penjumlahan skor setiap indikator dengan nilai minimum 0 dan nilai maksimum 18. Hasil penelitian diklasifikasikan sesuai distribusi data dengan perhitungan cut off point berdasarkan rerata \pm SD $(12,29 \pm 2,84)$. Berdasarkan hasil tersebut, maka praktik pemberian ASI dan MP-ASI dikategorikan buruk apabila $x<9,45$ cukup apabila skor berada pada $9,45 \leq x$ $\leq 15,13$ dan baik apabila $x \geq 15,14$.

Pengumpulan data variabel status ketahanan pangan rumah tangga menggunakan kuesioner USHFSSM (United State Household Food Security Survey Module) yang terdiri atas 18 pertanyaan dimana setiap jawaban afirmatif pada item pertanyaan diberi skor 1 . Status ketahanan pangan rumah tangga diklasifikasikan menjadi 4 kategori yaitu tahan pangan (skor 0-2), rawan pangan tanpa kelaparan (skor 3-7), rawan pangan dengan derajat kelaparan sedang (skor 8-12) dan rawan pangan dengan derajat kelaparan berat (skor 8-18) ${ }^{16}$.

Analisis data dilakukan untuk melihat perbedaan variabel pada kelompok balita gizi kurang dan normal menggunakan uji mann-whitney dengan tingkat kepercayaan $95 \%(\alpha=0,05)$. Penelitian ini telah lolos uji etik dengan nomor 447-KEKP dari komisi etik Fakultas Kesehatan Masyarakat Universitas Airlangga dan Badan Kesatuan Bangsa dan Politik (Bakesbangpol) Kota Surabaya dengan nomor 070/4319/436.8.5/2018 tanggal 25 Mei 2018.

\section{HASIL DAN PEMBAHASAN}

Karakteristik keluarga balita gizi normal dan gizi kurang dapat dilihat pada tabel 1 . Pendidikan terakhir ayah balita mayoritas adalah tamat SMA baik pada balita gizi normal (40\%) dan balita gizi kurang (35\%), pendidikan ibu balita dengan gizi normal mayoritas tamat SMA $(32,5 \%)$ sedangkan ibu balita dengan gizi kurang mayoritas adalah tamat SMP (35\%).

Pendidikan orang tua terutama pendidikan ibu, dapat menjadi faktor penyebab terjadinya masalah gizi pada balita, ibu merupakan orang yang memiliki peran penting terhadap pola asuh terutama pemberian makan, kesehatan anak serta berbagai aspek lain dalam keluarga ${ }^{17}$. Pendidikan dan pengetahuan yang baik membuat ibu mampu memilih dan memberikan makan yang tepat bagi balita sehingga status gizinya tetap baik ${ }^{18}$. Namun, pendidikan bukan satu-satunya faktor yang mempengaruhi tingkat pengetahuan, akan tetapi akses informasi juga perlu dipertimbangkan ${ }^{19}$. Kesungguhan orang tua untuk menggali informasi lebih banyak, dapat menjadi faktor penunjang meningkatnya pengetahuan orang tua sebagai upaya untuk mencegah berbagai masalah gizi, sebaliknya jika orang tua dengan pendidikan yang cukup baik namun dalam praktik pengasuhannya buruk, maka dapat pula menimbulkan masalah gizi ${ }^{20}$.

Tingkat pendapatan dan pengeluaran diklasifikasikan menjadi lima kategori berdasarkan distribusi data hasil penelitian. Pendapatan orang tua balita per bulan pada balita gizi normal mayoritas berada pada kuintil 4 (27,5\%) dengan kisaran Rp 2.800.001 - Rp 3.480 .000 sedangkan pada balita gizi kurang mayoritas pendapatan orang tua berada pada kuintil 2 (30\%) dengan kisaran Rp 1.720.001 - Rp 2.040.000. Kemampan ekonomi atau daya beli dari pendapatan merupakan faktor penting yang mempengaruhi akses terhadap makanan. Pada umumnya keluarga dengan pendapatan tinggi kemampuan daya beli akan meningkat sehingga lebih mudah mengakses makanan untuk dikonsumsi baik kualitas dan kuantitasnya, begitu juga dengan akses terhadap pelayanan kesehatan. Sedangkan pada rumah tangga dengan pendapatan rendah, kemampuan daya beli menurun sehingga menyebabkan makanan yang dipilih menjadi terbatas dan kurang beragam.

Pengeluaran untuk makan dalam keluarga pada pada tabel 1 menunjukkan sebagian besar berada pada kuintil 3 dengan kisaran pengeluaran sebesar $\mathrm{Rp}$ 1.000.001 - Rp 1.500.000 baik pada balita gizi normal dan gizi kurang. Namun, distribusi pengeluaran untuk makan dalam keluarga pada balita dengan gizi kurang cenderung pada kuintil yang rendah. Pengeluaran untuk konsumsi dapat berpengaruh terhadap status gizi balita, keluarga dengan pendapatan yang lebih tinggi, pengeluaran untuk makan cenderung lebih besar baik kualitas maupun kuantitasnya dibandingkan dengan keluarga dengan penghasilan rendah.

Jumlah anggota dalam keluarga adalah jumlah seluruh anggota keluarga yang berada dalam satu rumah dan mendapatkan makanan dari satu dapur yang sama. Pada balita gizi normal jumlah anggota dalam keluarga memiliki perbandingan yang sama, sementara pada balita dengan gizi kurang sebagian besar berasal dari keluarga besar dengan jumlah anggota $>4$ orang $(65 \%)$. Jumlah anggota dalam keluarga sering dikaitkan dengan masalah gizi pada balita, dimana jumlah anggota keluarga menjadi faktor yang menentukan distribusi makanan untuk seluruh anggota keluarga. Distribusi makanan menjadi semakin kecil dan tidak merata ketika jumlah anggota dalam keluarga semakin banyak, apalagi 
jika jumlah anggota yang banyak terjadi pada keluarga dengan ekonomi rendah.

Karakteristik balita pada tabel 2 menunjukkan bahwa mayoritas kelompok balita gizi normal dan gizi kurang berusia 12-24 bulan dengan masing-masing yaitu 24 balita (60\%) dan 32 balita (80\%). Jenis kelamin balita gizi kurang paling banyak adalah berjenis kelamin lakilaki (55\%), sedangkan pada balita dengan gizi normal yang berjenis kelamin laki-laki dan perempuan memiliki jumlah yang sama. Usia balita merupakan salah satu karakteristik yang menentukan pola konsumsi balita, balita pada umumnya diberi makan sesuai dengan usianya $^{21}$. Selain itu, jenis kelamin balita juga menentukan besar kebutuhan zat gizi dimana kebutuhan anak laki-laki biasanya lebih besar dari anak perempuan, karena aktivitas anak laki-laki yang lebih berat ${ }^{22}$. Oleh karena itu, salah satu hal yang penting untuk diperhatikan orang tua adalah pemenuhan kebutuhan gizi balita sesuai usia dan jenis kelamin melalui pola pengasuhan yang baik agar tumbuh kembang anak dapat optimal.

Praktik pemberian makan merupakan cara orang tua dalam memberikan makan berupa ASI dan MP-ASI yang dilihat berdasarkan delapan indikator yaitu Inisiasi Menyusu Dini (IMD), ASI eksklusif, keberlanjutan ASI, tekstur MP-ASI, frekuensi pemberian MP-ASI (Minimum Meal Frequency), Food Frequency, keberagaman jenis MP-ASI (Dietary diversity) dan konsumsi makanan mengandung Fe. Gambaran indikator praktik pemberian makan dapat dilihat pada tabel 3.

Tabel 1. Distribusi Karakteristik Keluarga pada Balita Gizi Normal dan Gizi Kurang di Kelurahan Tanah Kali Kedinding, Kecamatan Kenjeran, Kota Surabaya Tahun 2018.

\begin{tabular}{|c|c|c|c|c|}
\hline \multirow{2}{*}{ Karakteristik Keluarga } & \multicolumn{2}{|c|}{ Gizi Normal $(n=40)$} & \multicolumn{2}{|c|}{ Gizi Kurang $(n=40)$} \\
\hline & $\mathbf{n}$ & $\%$ & $\mathbf{n}$ & $\%$ \\
\hline \multicolumn{5}{|l|}{ Tingkat Pendidikan Ayah } \\
\hline Tamat SD & 6 & 15 & 12 & 30 \\
\hline Tamat SMP & 14 & 35 & 12 & 30 \\
\hline Tamat SMA & 16 & 40 & 14 & 35 \\
\hline Perguruan Tinggi & 4 & 10 & 2 & 5 \\
\hline \multicolumn{5}{|l|}{ Tingkat Pendidikan Ibu } \\
\hline Tamat SD & 9 & 22,5 & 13 & 32,5 \\
\hline Tamat SMP & 12 & 30 & 14 & 35 \\
\hline Tamat SMA & 13 & 32,5 & 11 & 27,5 \\
\hline Perguruan Tinggi & 6 & 15 & 2 & 5 \\
\hline \multicolumn{5}{|l|}{ Tingkat Pendapatan } \\
\hline Kuintil 1 ( $\leq \mathrm{Rp} 1.720 .000)$ & 5 & 12,5 & 11 & 27,5 \\
\hline Kuintil $2(\operatorname{Rp} 1.720 .001-\operatorname{Rp} 2.040 .000)$ & 4 & 10 & 12 & 30 \\
\hline Kuintil $3(\operatorname{Rp} 2.040 .000-\operatorname{Rp} 2.800 .000)$ & 10 & 25 & 9 & 22,5 \\
\hline Kuintil 4 (Rp 2.800.001 - Rp 3.480.000) & 11 & 27,5 & 3 & 7,5 \\
\hline Kuintil 5 (> Rp 3.480.000) & 10 & 25 & 5 & 12,5 \\
\hline \multicolumn{5}{|l|}{ Pengeluaran untuk Makan } \\
\hline Kuintil 1 ( $\leq$ Rp 760.000) & 3 & 7,5 & 11 & 27,5 \\
\hline Kuintil 2 (Rp $760.001-R p 1.000 .000)$ & 9 & 22,5 & 10 & 25 \\
\hline Kuintil $3(\operatorname{Rp} 1.000 .001-\operatorname{Rp} 1.500 .000)$ & 13 & 32,5 & 13 & 32,5 \\
\hline Kuintil 4 (Rp 1.500.001 - Rp 1.780.000) & 4 & 10 & 1 & 2,5 \\
\hline Kuintil 5 (>Rp 1.780.000) & 11 & 27,5 & 5 & 12,5 \\
\hline \multicolumn{5}{|l|}{ Jumlah Anggota dalam Keluarga } \\
\hline$\leq 4$ Orang & 20 & 50 & 14 & 35 \\
\hline$>4$ orang & 20 & 50 & 26 & 65 \\
\hline
\end{tabular}

Tabel 2. Distribusi Karakteristik Balita Gizi Normal dan Gizi Kurang di Kelurahan Tanah Kali Kedinding, Kecamatan Kenjeran, Kota Surabaya Tahun 2018.

\begin{tabular}{|c|c|c|c|c|}
\hline \multirow{2}{*}{ Karakteristik Balita } & \multicolumn{2}{|c|}{ Gizi Normal $(n=40)$} & \multicolumn{2}{|c|}{ Gizi Kurang $(n=40)$} \\
\hline & $\mathrm{n}$ & $\%$ & $\mathrm{n}$ & $\%$ \\
\hline \multicolumn{5}{|l|}{ Usia } \\
\hline $6-8$ Bulan & 10 & 25 & 6 & 15 \\
\hline $9-11$ Bulan & 6 & 15 & 2 & 5 \\
\hline $12-24$ Bulan & 24 & 60 & 32 & 80 \\
\hline \multicolumn{5}{|l|}{ Jenis Kelamin } \\
\hline Laki-Laki & 20 & 50 & 22 & 55 \\
\hline Perempuan & 20 & 50 & 18 & 45 \\
\hline
\end{tabular}


Tabel 3. Distribusi Frekuensi Indikator Praktik Pemberian Makan pada Balita Gizi Normal dan Gizi Kurang di Kelurahan Tanah Kali Kedinding, Kecamatan Kenjeran, Kota Surabaya Tahun 2018.

\begin{tabular}{|c|c|c|c|c|}
\hline \multirow{2}{*}{ Indikator Praktik Pemberian Makan } & \multicolumn{2}{|c|}{ Gizi Normal } & \multicolumn{2}{|c|}{ Gizi Kurang } \\
\hline & $\mathbf{n}$ & $\%$ & $\mathbf{N}$ & $\%$ \\
\hline \multicolumn{5}{|l|}{ Inisiasi Menyusu Dini } \\
\hline Hari & 14 & 35 & 15 & 37,5 \\
\hline Jam & 2 & 5 & 8 & 20 \\
\hline Segera & 24 & 60 & 17 & 42,5 \\
\hline \multicolumn{5}{|l|}{ ASI Eksklusif } \\
\hline Tidak & 19 & 47,5 & 22 & 55 \\
\hline Ya & 21 & 52,5 & 18 & 45 \\
\hline \multicolumn{5}{|l|}{ Keberlanjutan ASI } \\
\hline Tidak & 22 & 55 & 21 & 52,5 \\
\hline $\mathrm{Ya}$ & 18 & 45 & 19 & 47,5 \\
\hline \multicolumn{5}{|l|}{ Tekstur MP-ASI } \\
\hline Buruk & 6 & 15 & 12 & 30 \\
\hline Baik & 34 & 85 & 28 & 70 \\
\hline \multicolumn{5}{|l|}{ Frekuensi MP-ASI } \\
\hline Rendah & 5 & 12,5 & 11 & 27,5 \\
\hline Sedang & 24 & 60 & 24 & 60 \\
\hline Tinggi & 11 & 27,5 & 5 & 12,5 \\
\hline \multicolumn{5}{|l|}{ Food Frequency } \\
\hline Rendah & 2 & 5 & 3 & 7,5 \\
\hline Sedang & 6 & 15 & 3 & 7,5 \\
\hline Tinggi & 32 & 80 & 34 & 85 \\
\hline \multicolumn{5}{|l|}{ Keberagaman MP-ASI } \\
\hline Rendah & 4 & 10 & 5 & 12,5 \\
\hline Sedang & 10 & 25 & 11 & 27,5 \\
\hline Tinggi & 26 & 65 & 24 & 60 \\
\hline \multicolumn{5}{|l|}{ Konsumsi Makanan Mengandung Zat Besi (Fe) } \\
\hline Tidak & 11 & 27,5 & 16 & 40 \\
\hline $\mathrm{Ya}$ & 29 & 72,5 & 24 & 60 \\
\hline
\end{tabular}

Inisiasi Menyusu Dini (IMD) pada balita, sebagian besar dilakukan dengan segera setelah bayi dilahirkan baik pada balita gizi normal (60\%) dan balita gizi kurang (42,5\%). Melakukan IMD dengan segera dapat membatu bayi mendapatkan kolostrum yang terkandung pada Air Susu Ibu (ASI) untuk pertama kali, kolostrum kaya akan antibodi yang penting untuk ketahanan terhadap penyakit infeksi ${ }^{23}$.

Untuk indikator ASI eksklusif, terdapat 52,5\% balita dengan gizi normal yang mendapat ASI Eksklusif sedangkan pada balita gizi kurang yang mendapatkan ASI eksklusif lebih rendah yaitu $45 \%$. Pemberian Air Susu Ibu (ASI) selama 6 bulan sangat penting karena ASI mengandung nutrisi yang cukup dan zat kekebalan untuk melindungi balita dari penyakit infeksi sehingga balita yang diberi ASI tidak mudah terpapar penyakit infeksi ${ }^{24}$. Pemberian ASI sebelum 6 bulan dapat menimbulkan gangguan kesehatan karena sistem pencernaan belum sempurna ${ }^{25}$. Balita yang tetap mendapatkan ASI setelah usia 6 bulan dengan status gizi normal sebesar 45\%, sedangkan pada balita dengan gizi kurang sebesar 47,5\%. Setelah usia 6 bulan balita mulai bisa diperkenalkan makanan lain selain ASI, namun WHO merekomendasikan untuk tetap memberikan ASI setelah 6 bulan hingga usia 2 tahun. ASI yang diberikan hingga usia 2 tahun atau lebih bisa digunakan sebagai salah satu strategi potensial untuk memberikan perlindungan pada balita karena pada kenyataannya ASI tetap menjadi sumber kekebalan tubuh, nutrisi dan mikronutrien bagi balita 26 .

Tekstur Makanan Pendamping ASI (MP-ASI) harus diberikan secara bertahap sesuai dengan usia balita mulai makanan yang lunak, semi padat hingga makanan padat. Pada balita gizi nomal, tekstur makanan sebagian besar sudah diberikan dengan baik ( $85 \%)$ yaitu memberikan jenis makanan dengan tekstur yang disesuaikan dengan usia balita, sedangkan pada balita gizi kurang jumlahnya lebih rendah yaitu (70\%). Frekuensi pemberian MP-ASI sebagian besar diberikan dalam kategori sedang, baik balita gizi normal (60\%) dan gizi kurang (60\%), frekuensi pemberian MP-ASI dikategorikan sedang apabila diberikan sebanyak 2 kali pada usia 6-8 bulan, 3 kali pada usia 9-11 bulan dan 1224 bulan 27.

Food Frequency dilihat berdasarkan 7 jenis kelompok makanan yang dikonsumsi selama 7 hari terakhir sebelum wawancara dengan menggunakan Food Frequency Questionnaire (FFQ), kelompok makanan tersebut antara lain makanan pokok, kacang-kacangan, produk olahan susu, daging dan ikan, telur, buah dan sayur sumber vitamin A serta buah dan sayur lainnya. Hasil penelitian pada balita di Kelurahan Tanah Kali Kedinding rata-rata frekuensi konsumsi kelompok makanan pada balita status gizi normal sebagian besar tergolong dalam kategori tinggi dengan persentase sebesar $80 \%$, begitu 
Tabel 4. Perbedaan Praktik Pemberian Makan dan Status Ketahanan Pangan Rumah Tangga pada balita dengan Status Gizi Normal dan Gizi Kurang di Kelurahan Tanah Kali Kedinding, Kecamatan Kenjeran, Kota Surabaya Tahun 2018

\begin{tabular}{lccccc}
\hline \multicolumn{1}{c}{ Variabel } & \multicolumn{2}{c}{ Gizi Normal } & Gizi Kurang & \multirow{2}{*}{ Nilai $\boldsymbol{p}$} \\
\cline { 2 - 5 } & $\mathbf{n}$ & $\mathbf{\%}$ & $\mathbf{n}$ & $\mathbf{\%}$ & \\
\hline Praktik Pemberian Makan & 3 & 7,5 & 10 & 25 & 0,032 \\
$\quad$ Buruk & 31 & 77,5 & 27 & 67,5 & \\
$\quad$ Cukup & 6 & 15 & 3 & 7,5 & \\
$\quad$ Baik & & & & & \\
\hline Status Ketahanan Pangan Rumah Tangga & 0 & 0 & 3 & 7,5 & \\
$\quad$ Rawan Pangan dengan Kelaparan Berat & 5 & 12,5 & 5 & 12,5 & 0,012 \\
Rawan Pangan dengan Kelaparan Sedang & 10 & 25 & 19 & 47,5 & \\
Rawan Pangan tanpa Kelaparan & 25 & 62,5 & 13 & 32,5 & \\
Tahan Pangan & & &
\end{tabular}

juga pada balita status gizi kurang sebagian besar tergolong kategori tinggi (85\%). Keragaman Jenis MP-ASI dilihat berdasarkan jumlah 7 kelompok makanan yang dikonsumsi selama satu hari terakhir sebelum wawancara dengan menggunakan form recall 24 jam. Hasil penelitian pada tabel 3 dapat digambarkan bahwa keragaman MP-ASI balita berada pada tingkat keberagaman tinggi (65\%) untuk balita gizi normal dan balita gizi kurang (60\%).

Status gizi yang baik terjadi apabila tubuh memperoleh cukup zat gizi, baik zat gizi makro maupun mikro yang digunakan dalam pertumbuhan fisik serta perkembangan otak, salah satu zat gizi mikro yang berperan dalam perkembangan adalah zat besi $(\mathrm{Fe})^{28}$. Pada tabel 3 dapat dilihat bahwa sebagian besar balita gizi normal mengkonsumsi makanan yang mengandung zat besi $(72,5 \%)$, begitu pula dengan balita dengan gizi kurang $(60 \%)$

Pengkategorian variabel praktik pemberian makan dilakukan dengan memberikan skoring pada masing-masing indikator dan hasilnya diklasifikasikan menjadi tiga kategori yaitu baik, cukup dan buruk. Gambaran praktik pemberian makan dapat dilihat pada tabel 4 dimana pada balita gizi normal sebagian besar tergolong dalam kategori cukup (77,5\%), begitu juga dengan balita gizi kurang sebagian besar tergolong dalam kategori cukup $(67,5 \%)$, praktik pemberian makan dengan kategori buruk pada balita gizi normal $(7,5 \%)$ lebih rendah dibandingkan dengan balita gizi kurang (25\%).

Hasil uji statistik menggunakan uji MannWhitney menunjukkan adanya perbedaan praktik pemberian makan antara balita dengan status gizi normal dan gizi kurang $(p=0,032)$. Praktik pemberian makan oleh orang tua yang mencakup pemberian ASI dan MP-ASI merupakan salah satu penyebab tidak langsung yang mempengaruhi status gizi. Praktik pemberian makan secara langsung akan mempengaruhi asupan zat gizi balita, jika praktik pemberian makan dilakukan dengan baik maka asupan zat gizi bagi balita dapat terpenuhi sehingga status gizinya normal.

Status ketahanan pangan rumah tangga adalah kondisi pangan dalam rumah tangga yang dinilai secara kualitatif menggunakan instrumen United States Household Food Security Survey Module (US-HFSSM). Gambaran status ketahanan pangan rumah tangga dapat dilihat pada tabel 4 dimana pada balita gizi normal sebagian besar rumah tangga berstatus tahan pangan $(62,5 \%)$. Sementara itu, pada balita gizi kurang sebagian besar rumah tangga mengalami rawan pangan tanpa kelaparan $(47,5 \%)$. Berdasarkan hasil penelitian juga diketahui bahwa pada balita gizi normal tidak ada rumah tangga yang berstatus rawan pangan dengan derajat kelaparan berat, sedangkan pada balita gizi kurang terdapat rumah tangga yang berstatus rawan pangan dengan derajat kelaparan berat $(7,5 \%)$.

Hasil uji statistik menggunakan uji MannWhitney menunjukkan adanya perbedaan status ketahanan pangan rumah tangga pada balita dengan status gizi normal dan status gizi kurang. Hal tersebut serupa dengan penelitian yang pernah dilakukan bahwa terdapat perbedaan status ketahanan pangan pada kelompok balita dengan status gizi normal dan status gizi kurang ${ }^{19}$. Balita yang berasal dari rumah tangga rawan pangan berisiko 3,82 kali mengalami underweight dibandingkan dengan balita yang berasal dari rumah tangga tahan pangan ${ }^{29}$

Status gizi balita berhubungan langsung dengan dua faktor yaitu asupan zat gizi dan penyakit infeksi, kedua faktor tersebut terkait dengan berbagai penyebab tidak langsung, salah satunya yaitu ketahanan pangan rumah tangga. Status ketahanan pangan rumah tangga menggambarkan tingkat ketersediaan pangan di dalam rumah baik dari segi kualitas maupun kuantitasnya. Ketahanan pangan rumah tangga tidak hanya dilihat dari kemampuan rumah tangga untuk menyediakan pangan dalam keluarga, namun juga memperhatikan dimensi waktu dan stabilitas tiap sub sistem ${ }^{20}$. Ketahanan pangan yang baik akan menghasilkan ketahanan gizi yang baik, ketahanan gizi yang meliputi intake gizi dan status gizi menjadi prasyarat terbentuknya individu yang sehat, timbulnya masalah gizi kurang adalah indikasi kurangnya ketahanan gizi.

Rendahnya pendapatan dapat menjadi salah satu faktor penyebab terjadinya gizi kurang pada balita, berdasarkan karakterisktik keluarga responden di Kelurahan Tanah Kali Kedinding diketahui bahwa balita dengan status gizi kurang sebagian besar berasal dari keluarga dengan pendapatan rendah serta rata-rata pengeluaran untuk makan juga rendah. Tingkat pendapatan dan tingkat pengeluaran pangan yang rendah dapat menyebabkan rendahnya daya beli sehingga ketersediaan bahan pangan yang berperan terhadap tingkat konsumsi balita tidak optimal dan pada 
akhirnya akan berdampak pada status gizi balita akibat pemenuhan asupan zat gizi dari makanan tidak dapat tercukupi dengan baik.

\section{KESIMPULAN}

Terdapat perbedaan praktik pemberian makan pada balita usia $6-24$ bulan dengan status gizi normal dan status gizi kurang di Kelurahan Tanah Kali Kedinding Kota Surabaya. Balita dengan status gizi kurang cenderung mendapat praktik pemberian makan yang cukup dan buruk. Terdapat perbedaan status ketahanan pangan rumah tangga pada balita usia $6-24$ bulan dengan status gizi normal dan status gizi kurang di Kelurahan Tanah Kali Kedinding Kota Surabaya. Balita dengan status gizi normal sebagian besar berasal dari rumah tangga tahan pangan dan tidak ada yang berasal dari rumah tangga dengan derajat kelaparan berat.

Diperlukan upaya peningkatan pola asuh yang menekankan pada aspek praktik pemberian makan dengan mengoptimalkan kegiatan penyuluhan tentang pemberian makanan yang tepat untuk balita serta kerja sama antara stakeholder dan masyarakat untuk pengembangan pangan pada level rumah tangga dengan cara yang mudah seperti penggunaan media polybag, serta memanfaatkan pangan lokal seperti hasil laut untuk memberikan makanan tambahan kepada balita. Diperlukan penelitian lanjutan terkait dengan faktor lain yang berhubungan dengan status gizi balita seperti penyakit infeksi, sanitasi tempat tinggal serta aspek subsistem ketahanan pangan yaitu ketersediaan, akses, pemanfaatan dan stabilitas pangan.

\section{ACKNOWLEDGEMENT}

Penulis mengucapkan terima kasih kepada Badan Kesatuan Bangsa dan Politik (Bakesbangpol) Kota Surabaya, Dinas Kesehatan Kota Surabaya, Dinas Ketahanan Pangan dan Pertanian Kota Surabaya, Puskesmas Tanah Kali Kedinding, kader posyandu Puskesmas Tanah Kali Kedinding yang telah memberikan izin dan membantu pelaksanaan penelitian ini. Seluruh staf dan dosen Departemen Gizi Kesehatan dan Program Studi Kesehatan Masyarakat FKM UNAIR terutama dosen pembimbing yang telah memberikan bimbingan dan dukungan selama penelitian.

\section{REFERENSI}

1. Indrasari, O. R. \& Kesehatan, F. I. Hubungan Pengetahuan Ibu Tentang Gizi dengan Perkembangan Motorik Halus pada Balita. J. IKESMA 12, 113-119 (2016).

2. Natalia, L. D., Dina, R. \& Fatimah, S. Hubungan Ketahanan Pangan Tingkat Keluarga dan Tingkat Kecukupan Zat Gizi dengan Status Gizi Batita di Desa Gondangwinangun Tahun 2012. J. Kesehat. Masy. 2, 340-348 (2013).

3. Pusat Data dan Informasi Kementerian Kesehatan RI. Data and Information Indonesia Health Profile 2016. (2016).
4. Dinas Kesehatan Kota Surabaya. Profil Kesehatan Kota Surabaya Tahun 2014. (2014).

5. Dinas Kesehatan Kota Surabaya. Profil Kesehatan Kota Surabaya, tahun 2015. (2015). Available at: http://www.depkes.go.id/resources/download/p rofil/PROFIL_KAB_KOTA_2015/3578_Jatim_Kota _Surabaya_2015. (Accessed: 18th May 2017)

6. Dinas Kesehatan Kota Surabaya. Profil Kesehatan Kota Surabaya Tahun 2016. (2016).

7. Larasati, W. Hubungan antara Praktik Pemberian Makanan Pendamping ASI (MP-ASI) dan Penyakit Infeksi Kaitannya dengan Status Gizi pada Bayi Usia 6-12 Bulan. Digilib UNNES (2011).

8. WHO. Infant and young child feeding. World Health 155, A3929 (2011).

9. Rikantasari, S. Pemberian Makanan terhadap Batita di Pemukiman Tanah Kalikedinding, Kecamatan Kenjeran, Surabaya. J. UNAIR 1, 5568 (2010).

10. Ali Naser, I. et al. Association between household food insecurity and nutritional outcomes among children in Northeastern of peninsular Malaysia. Nutr. Res. Pract. 8, 304-311 (2014).

11. The Economist Intelligence Unit. Global Food Security Index. Global Food Security Index (2017).

12. Badan Ketahanan Pangan. Laporan Tahunan Badan Ketahanan Pangan 2016. Kementrian Pertanian (2017).

13. Badan Ketahanan Pangan. Peta Ketahanan dan Kerentanan Pangan Jawa Timur 2015. (2015).

14. Rachman, H. P. . \& Ariani, M. Ketahanan Pangan: Konsep, Pengukuran dan Strategi. FAE 20, 12-24 (2002).

15. Organization, W. H. Indicators for assessing infant and young child feeding practices. World Health (2010). doi:ISBN 9789241599757

16. Bickel, G., Nord, M., Price, C., Hamilton, W. \& Cook, J. Guide to Measuring Household Food Security Revised 2000. Agriculture 1-76 (2000).

17. Damanik, M. R., Ekayanti, I. \& Hariyadi, D. Analisis Pengaruh Pendidikan Ibu Terhadap Status Gizi Balita Di Provinsi Kalimantan Barat. J. Gizi dan Pangan 5, 69 (2010).

18. Aryanti, M. A. Hubungan antara pendapatan Keluarga, Pengetahuan Gizi Ibu, dan Pola Makan dengan Status Gizi Balita di Wilayah Kerja Puskesmas Sidoharjo Kabupaten Sragen. Universitas Negeri Semarang (2010).

19. Rahma, A. C. \& Nadhiroh, S. R. Perbedaan Sosial Ekonomi Dan Pengetahuan Gizi Ibu Balita Gizi Kurang Dan Gizi Normal. Media Gizi Indones. 11, 55-60 (2016).

20. Al-Isyrofi, A. Q. A. Hubungan Antara Pola Asuh dan Status Ketahanan Pangan Rumah Tangga dengan Status Gizi Balita (2-5 Tahun) pada Pemukiman Kumuh di Kecamatan Bulak Kota Surabaya. (Universitas Airlangga, 2016).

21. Sulistyoningsih, H. Gizi untuk Kesehatan Ibu dan Anak. (Graha IImu, 2011).

22. Nugroho, B. F. D., Endah, S. \& Ernawati, Y. Karakteristik Perilaku Pemberian Makan Dan 
Status Gizi Anak Usia 1-3 Tahun Di Posyandu Kuncup Melati Puskesmas. J. Unimus 297-304 (2014).

23. Putri, M. S., Kapantow, N. \& Kawengian, S. Hubungan antara riwayat penyakit infeksi dengan status gizi pada anak batita di Desa Mopusi Kecamatan Lolayan Kabupaten Bolaang Mongondow. J. E-Biomedik 3, 1-5 (2015).

24. Adriani, M. \& Wirjatmadi, B. Peranan Gizi dalam Siklus Kehidupan. (Kencana, 2012).

25. Darmawan, F. H., Nur, E. \& Sinta, M. Hubungan Pengetahuan Dan Sikap Ibu Dengan Perilaku Pemberian Mp-Asi Yang Tepat Pada Bayi Usia 612 Bulan. 1, 32-42 (2015).

26. Delgado, C. \& Matijasevich, A. Breastfeeding up to two years of age or beyond and its influence on child growth and development: a systematic review. Cad. Saude Publica 29, 243-256 (2013).

27. Lohia, N. \& Udipi, S. A. Infant and child feeding index reflects feeding practices, nutritional status of urban slum children. BMC Pediatr. 14, 1-11 (2014).

28. Wadhani, L. P. P. \& Yogeswara, I. B. A. Tingkat konsumsi zat besi ( Fe ), seng ( $\mathrm{Zn}$ ) dan status gizi serta hubungannya dengan prestasi belajar anak sekolah dasar. Gizi Indones. 5, 82-87 (2017).

29. Betebo, B., Ejajo, T., Alemseged, F. \& Massa, D. Household Food Insecurity and Its Association with Nutritional Status of Children 6-59 Months of Age in East Badawacho District, South Ethiopia. J. Environ. Public Health 2017, (2017). 